Arab Univ. J. Agric. Sci., Ain Shams Univ., Cairo, 14(2), 593-611, 2006

\title{
STUDIES ON DETECTION, DIAGNOSIS AND CONTROL OF LEGIONELLA PNEUMOPHILA IN DIFFERENT WATER SAMPLES
}

[38]

\author{
Mansour $^{1}$, F.A.; S.A. El-Sherbiny ${ }^{2}$ and N.A. El-Morsy ${ }^{3}$
}

\begin{abstract}
A number of 192 samples (180 water \& swab specimens and 12 patient sputa) were chosen from different sites of Mansoura University Hospitals for detection and diagnosis of Legionella pneumophila. Out of the 192 samples, 148 were positive by culture method and non-specific staining technique such as gram staining and biochemical analysis. In our trials for diagnosis of Legionella pneumophila, we found that 107 of 148 samples were positive by slide agglutination test and 110 samples were positive by direct immunoflourescence assay, while 130 samples were positive by polymerase chain reaction (PCR) technique which proved to be the most specific and sensitive technique for diagnostic investigation of L. pneumophila. The results show that the four disinfectant procedures (chlorine, ozone, U.V. light and heat) were effective in eradicating Legionella pneumophila from different water samples. Both UV light and heat $\left(60^{\circ} \mathrm{C}\right)$ produced a $5 \log$ kill in less than $1 \mathrm{~h}$. In contrast, both chlorine and ozone required $5 \mathrm{~h}$ of exposure to produce a $5 \log$ decrease. Neither turbidity nor the higher temperature of $43^{\circ} \mathrm{C}$ impaired the efficacy of any of the disinfectant methods.
\end{abstract}

Keywords: Sputa, Legionella pneumophila, U.V. light, Disinfectants, Immunoflourescence assay.

\section{INTRODUCTION}

The genus Legionella, Family Legionellaceae contains at least 22 species most of which have yet to be isolated from clinical specimens (Campbell et al 1984; Gondaira \& Sugiyama, 1996 and Buising et al 2001). Members of this genus are nutritionally fastidious, gramnegative, non-sporeforming bacilli and most not all species are motile by virtue of one or two monopolar flagellae (Hart and Makin, 1991).

The legionellae are the causative agents of legionnaires disease, a multisystem disease manifested primarily as pneumonia (Meyers, 1983; Hart \& Makin, 1991; Formica et al 2000 and Gracia et al 2003).

1- Botany Department, Faculty of Science, Mansoura University, Mansoura, Egypt

2- Botany Department, Faculty of Science, Zagazig University, Zagazig, Egypt

3- Digestive System Center, Mansoura University Hospital, Mansoura, Egypt. 
The major reservoirs of Legionella species appear to be fresh-water sites, airconditioning units and various potable water systems (Fliermans, 1983 and Torrijos et al 1995).

The only criterion used to distinguish species of Legionella has been DNA hybridization studies (Jones and Hebert, 1979) and phenotypic traits such as pigmentation, autofluorescence, gelatinase production, hippurate hydrolysis and cellular fatty acids. Serotyping plays a major role in species and subgroups identification (Bibb et al 1981 and Formica et al 2001).

There are many methods of varying efficacy for controlling legionellae in hospital hot water systems. They fall into three categories : physical, chemical, and good plumbing practice such as heat, UV, sonication, draining and flushing with compressed air, sodium hypochlorite and ozone (Muraca et al 1995 and Hoebe and Kool, 2000).

The present study was conducted to find out reliable methods for detection, diagnosis and control of Legionella pneumophila in different water system in Mansoura University Hospitals.

\section{MATERIAL AND METHODS}

\section{Sampling}

One hundred and twenty tap water samples from bathrooms, twenty water samples, forty swab samples and twelve sputum samples were collected under complete aseptic conditions from different sites of Mansoura University Hospitals (Table 1). Samples were transported immediately in sealed containers to the laboratory. Two liters of water were col- lected upon two occasions, one liter each, during the period from October, 1996 to April, 1997.

The positive control reference of all laboratory diagnostic techniques for $L$. pneumophila serotype 1 is strain Philadelphia 1 (ATCC 33152) that has been kindly supplied by Prof. Dr. Helmy T. ElZanfaly, Water Pollution Department, National Research Center, Dokki, Egypt.

\section{Cultivation of Legionellas}

The recommended culture medium is BCYE agar medium (buffered charcoalyeast extract agar); this is proved more satisfactory than the enriched blood agar media described by Greaves (1980).

\section{Methodology}

The following laboratory investigations were done to all specimens and to positive control references:

\section{1- Methods of Isolation and Culture Conditions}

Isolation of L. pneumophila from water and water systems was carried out using the methods of Arnow et al (1985) and Ribeiro et al (1987).

\section{2- Morphological characteristics}

Including colonial characteristics, shape \& size of cells, and staining reaction. The isolation of a single bacterium and formation of separate colonies was carried out according to the technique of (Boyd and Marr, 1980). 


\section{3- Biochemical reactions}

3-1. Hipurate hydrolysis, was tested following the method adopted by Baer and Dasis (1981).

3-2. Catalase test, was carried out following the procedures described by Boyd and Marr (1980).

3-3. Gelatin liquefaction test, was performed as described by Boyd and Marr (1980).

3-4. Starch hydrolysis test, was carried out as described by Baker and Breach (1980).

3-5. Oxidase test, was carried out as described by Smith (1980).

\section{4- Antibiotic sensitivity test}

This can be demonstrated by disk diffusion method (Finegold and Martin, 1982).

\section{5- Serotyping of Legionella by Latex Agglutination Test (Mast Diagnos- tica)}

Agglutination test was performed by the method described by(Harrison and Taylor 1988).

\section{6- Direct immunofluorescence test (DFT)}

The direct immunofluorescence test (DFT) was carried out using direct immunofluorescence for the detection of Legionella pneumophila with monoclonal antibodies (Freka fluor L. pneumophila MAB DFT).

\section{7- Polymerase Chain Reaction (PCR) Technique}

Diagnosis of L. pneumophila by PCR was carried out according to the method of Koide and Saito (1995). The PCR reaction mixture contained $10 \mathrm{mM}$ Tris$\mathrm{HCl}$ (pH 8.3), $50 \mathrm{mM} \mathrm{KCl}, 1.5 \mathrm{mM}$ $\mathrm{MgCl}_{2}, 10 \mathrm{mg}$ of gelatin per liter, deoxy nucleotide triphosphatase (each at a concentration of $200 \mu \mathrm{M}$ ), primers (each at a concentration of $50 \mathrm{pM}$ ), and $2.5 \mu$ of Taq DNA polymerase.

\section{8- Efficacy of disinfectants on $L$. pneu- mophila from Potable Water Sys- tem}

To compare the efficacy of ozonation, UV light, hyperchlorination and heat disinfection, a model plumbing system was constructed of copper piping, brass spigots, Plexiglass reservoir, electric hot water tank, and a pump (Muraca et al 1995). Legionella pneumophila was added to the system at $10^{7} \mathrm{CFU} / \mathrm{ml}$. Each disinfectant was tested under three conditions:

i) Nonturbid water at $25^{\circ} \mathrm{C}$.

ii) Turbid water at $25^{\circ} \mathrm{C}$.

iii) Nonturbid water at $43^{\circ} \mathrm{C}$.

Before each experimental run, the system was filled with hot sterile tap water $80^{\circ} \mathrm{C}$, each sample port was purged and the water was recirculated for no longer than $24 \mathrm{~h}$. This served to flush the system of all bacterial contaminants and provided a sterile baseline environment. 


\section{RESULTS AND DISCUSSION}

\section{Detection and Isolation of Legionella pneumophila in Water Systems and Patient Sputa}

In the present investigation a number of 180 water samples \& 12 sputum samples were collected from different sites of Mansoura University Hospitals and cultured on BCYE agar medium, according to the methods described by Ribiero et al (1987). The results (Table 1) show that all samples from air conditioning sites, patient sputa (from patients with liver disease and patients subjected to renal transplantation) as well as water speci- mens from air conditioners showed $100 \%$ growth of $L$. pneumophila with mean viable count of $3.2 \times 10^{2}, 4 \times 10,1.4 \times$ 10 and $1.8 \times 10^{3} \mathrm{CFU} / 100 \mathrm{ml}$, respectively. These results indicate that, $L$. pneumophila is more frequent in sputa \& water samples from air conditioning sites rather than water samples from mixer taps and water samples from water taps. Jaulhac et al (1998) reported that Legionnaires disease occurred in at least $25 \%$ of immunosuppressed patients exposed to aerosolized tap water containing Legionella with viable count of L. pneumophila $100 \mathrm{CFU} / \mathrm{liter}$, whereas no cases were detected among 160 nonimmunosuppressed patients who were similarly exposed.

Table 1. The percentage incidence of Legionella pneumophila in different samples.

\begin{tabular}{|lcc|}
\hline \multicolumn{1}{|c}{ No. of Sites } & $\%$ of Positive growth & No. of CFU/100ml \\
\hline 20 Hot water from mixer taps & $95 \%$ & $2.7 \times 10^{4}$ \\
20 Cold water from mixer taps & $75 \%$ & $1.2 \times 10^{3}$ \\
20 Cold water from showers & $60 \%$ & $6.4 \times 10^{2}$ \\
20 Hot water from showers & $80 \%$ & $3.0 \times 10^{3}$ \\
20 Hot water from water taps & $85 \%$ & $8.0 \times 10^{3}$ \\
20 Cold water from water taps & $45 \%$ & $1.0 \times 10^{2}$ \\
20 Water specimens from air condition & $100 \%$ & $1.8 \times 10^{3}$ \\
10 Swabs from sink and bath hot tap & $95 \%$ & $6.4 \times 10^{3}$ \\
10 Swabs from sink and bath cold tap & $90 \%$ & $5.0 \times 10^{2}$ \\
10 Swabs from shower roses & $90 \%$ & $4.2 \times 10^{3}$ \\
10 Swabs from air condition sets & $100 \%$ & $3.2 \times 10^{2}$ \\
8 Liver disease patients sputa & $100 \%$ & $4.0 \times 10$ \\
4 Renal transplantation & $100 \%$ & $1.4 \times 10$ \\
\hline
\end{tabular}




\section{Morphological features of the Isolated Bacterium}

The reference strains of $L$. pneumophila produces, on buffered charcoalyeast agar medium (BCYE), circular colonies having smooth glistening surface, entire crenated edges, soft butyrous consistency with grey to grey-blue colorful appearance. The bacterial isolates that exhibit more or less similar characteristics are considered as presumptive positive L. pneumophila (Fig. 1 a and 1b).

The gram stain reaction shows negative, non-sporeforming short rods, they range in size and shape from uniform small bacilli 0.5 by $2.0 \mu \mathrm{m}$ diameter by $100 \mu \mathrm{m}$ length (Fig. 2).

\section{Biochemical characteristics}

The results revealed that, the isolates obtained from water samples, swab and patient sputa, showed positive hipurate hydrolysis, positive to catalase test, gelatin liquefact, starch hydrolysis and oxidase test. These tests indicate that these isolates belong to L. pneumophila.

\section{Antibiotic sensitivity test}

Antibiotic sensitivity test (Fig. 3 a $\boldsymbol{\&}$ b) revealed that $L$. pneumophila was highly sensitive to chloramphenicol (C), erythromycin $(\mathrm{E})$ and gentamycin $(\mathrm{CN})$ followed by doxycycline hydrochloride (Do), rifampicine (RA) and cephalexin (CL). This is in agreement with Smith et al (1997), who found that the MIC for the L. pneumophila isolate of chloramphenicol, erythromycin and rifampicine was $0.3,0.5$ and $0.001 \mathrm{mg} / \mathrm{L}$, respectively. In another study, Higa et al (1998) stated that, the MIC for the L. pneumophila isolate of gentamycin, doxycycline hydroch- loride and cephalexin was 0.02, 0.003, $0.001 \mathrm{mg} / \mathrm{L}$, respectively.

\section{Serotyping}

Serotyping was performed using agglutination test and direct immunofluorescent techniques. Only 107 of 148 positive sample by culture were positive by agglutination test (Tables 2 \& 3). We found that 127 samples were positive by this test for serotypes (1-14), the maximum no. were positive for serotype 9 $(14 / 127 \cong 11 \%)$ and the minimum no. were positive for serotype $13(1 / 127 \cong$ $0.78 \%$ ). In this study, serotype 6 was not appear by using this technique because agglutination tests measures primarily IgM antibody. Therefore, they may lack sufficient sensitivity for immunodiagnostic assay (Miyamato et al 1995). Wilkinson and Fikes (1990) reported that agglutination test is simple and specific and requires no expensive equipment or conjugates.

The direct immunofluorescence study showed green fluorescence bacilli (Fig. 4), 110 out of 192 samples were positive to this test, with high positive rate in case of serotype $1(17.27 \%)$, and less positive rate in serotype 14 (1.8\%) (Table 4).

\section{Polymerase chain reaction (PCR)}

In our trials to examine the best and rapid method for L. pneumophila diagnosis, we examined the application of the polymerase chain reaction (PCR) for the diagnosis of Legionella, we found that 130 of 148 positive samples by culture were positive by PCR and this ratio is higher than the DFT (110). We use two specific primers synthesized according to the reported L. pneumophila mip gene nucleotide sequence. 
Fig. 1-a. Buffered Charcoal Yeast Extract (BCYE) agar plate showing Legionella colonies

Fig. 1-b. Magnification of Legionella colonies showing the characteristic structure of the colony /(gray colored with hallow zone around each colony).

Fig. 2. Gram stained film from presumptive L. pneumophila culture showing Gram negative non performing rods (bacilli), they range in size and shape from uniform small bacilli 0.5 by $2.0 \mu \mathrm{m}$. 


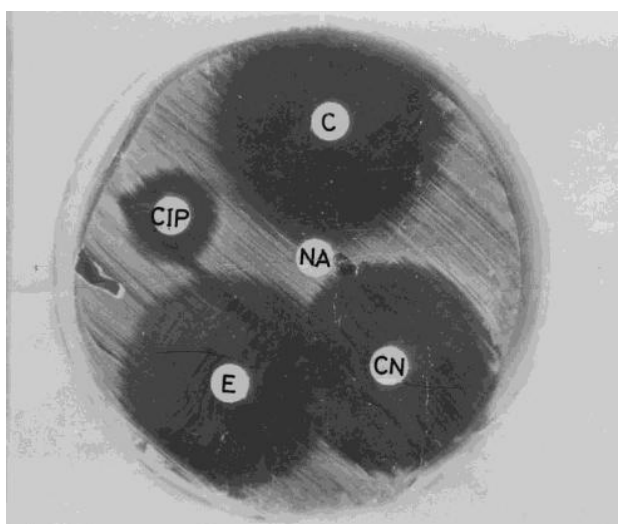

Fig. 3-a. Antibiotic sensitivity test for Legionella showing; sensitive to; Gentamicin $(\mathrm{CN})$, Erythromycin (E) and choloramphenico (C); resistant to; Nalidixic acid (NA) and Ciprinol (CIP).

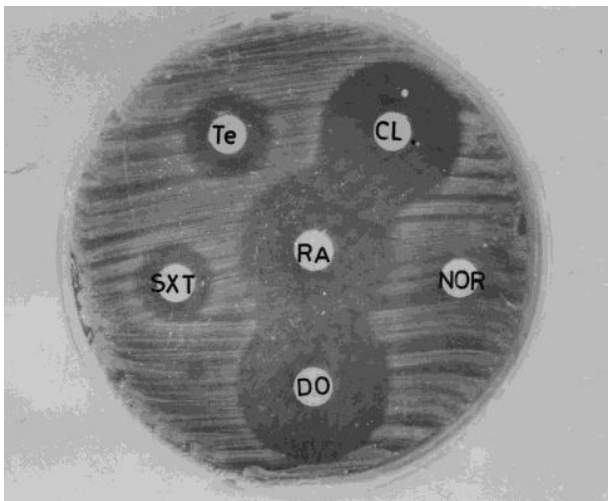

Fig. 3-b. Antibiotic sensitivity test for Legionella, it is sensitive to; Doxycycline hydrochloride (Do), Rifampicine (RA), and Cephalexin (CL), and resistant to; Salphamethoxazole trimethoprim (SXT), tetracycline (TE), and Noroxine (NOR).

Table 2. Strength of agglutination reaction test.

\begin{tabular}{|lccccccc|}
\hline \multirow{2}{*}{ Sample } & \multirow{2}{*}{$\begin{array}{c}\text { Number of } \\
\text { sampled }\end{array}$} & \multicolumn{2}{c}{ Positive } & \multicolumn{4}{c|}{ Strength* } \\
\cline { 3 - 8 } & No. & $\%$ & $1+$ & $2+$ & $3+$ & $4+$ \\
\hline Water & $(140)$ & 85 & $60 \%$ & 10 & 20 & 25 & 30 \\
Swabs & $(40)$ & 30 & $75 \%$ & - & - & 10 & 20 \\
Patients & $(12)$ & 12 & $100 \%$ & - & - & 8 & 4 \\
\hline
\end{tabular}

$1+:$ Light agglutination with suspension $2+:$ Heavy agglutination with suspension

Arab Univ. J. Agric. Sci., 14(2), 2006 
$3+$ : Light agglutination with clear zone $4+$ : Heavy agglutination with clear zone

Tables 3. L. pneumophila serotype by using latex agglutination test (serotype 1-14).

\begin{tabular}{|c|c|c|c|c|c|c|c|c|c|c|c|c|c|c|c|c|}
\hline \multirow{2}{*}{$\begin{array}{c}\text { No. of } \\
\text { specimens }\end{array}$} & \multicolumn{8}{|c|}{ Positive } & \multicolumn{8}{|c|}{ Serotypes } \\
\hline & No & $\%$ & 1 & 2 & 3 & 4 & 5 & 6 & 7 & 8 & 9 & 10 & 11 & 12 & 13 & 14 \\
\hline $\begin{array}{l}140 \text { water } \\
\text { sample }\end{array}$ & 85 & 60 & 5 & 6 & 4 & 7 & 20 & - & 8 & 5 & 10 & 2 & 2 & 7 & 6 & 3 \\
\hline 40 Swabs & 30 & 75 & 3 & 2 & 5 & 4 & 6 & - & - & 2 & 3 & 2 & 1 & - & - & 2 \\
\hline $\begin{array}{l}12 \text { Patient spu- } \\
\text { ta }\end{array}$ & 12 & 100 & - & 2 & 1 & 1 & - & - & 2 & 1 & 1 & 2 & 1 & - & 1 & - \\
\hline
\end{tabular}

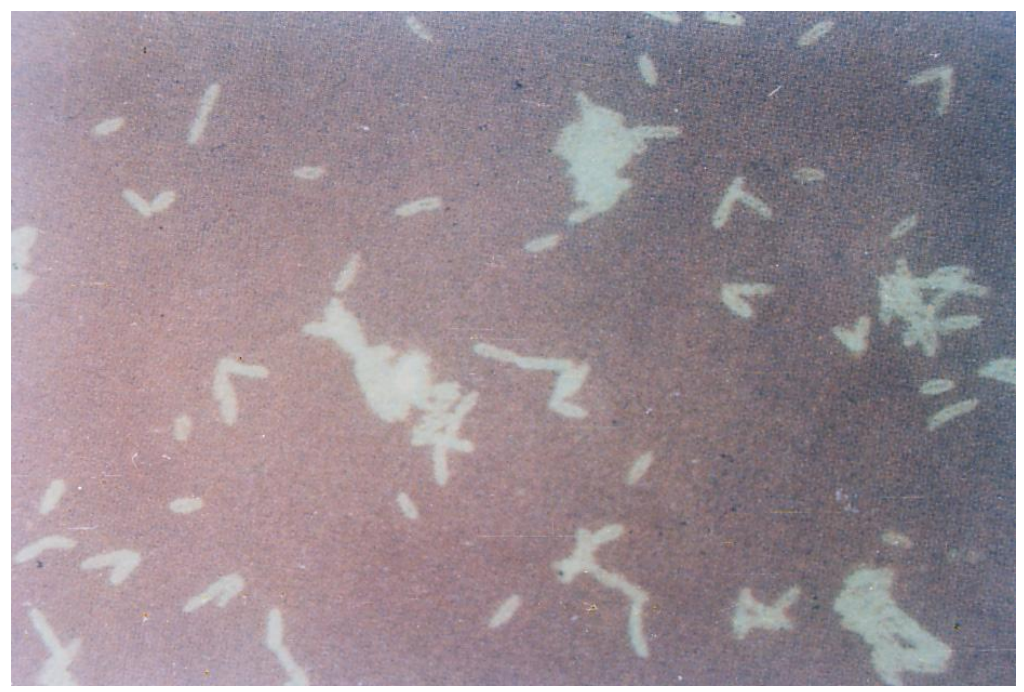

Fig. 4. DET using (FITC) labeled anti-L. pneumophila monoclonal antibody (mouse) the bacilli green fluorescence under the fluorescent microscope. 
Table 4. Direct immunofluorescence test* for L. pneumophila In 192 samples from different sources.

\begin{tabular}{|cc|}
\hline Organism & Positive \\
\hline L. pneumophila serotype & \\
1 & 19 \\
2 & 10 \\
3 & 5 \\
4 & 8 \\
5 & 6 \\
6 & 8 \\
7 & 13 \\
8 & 6 \\
9 & 8 \\
10 & 8 \\
11 & 9 \\
12 & 5 \\
13 & 3 \\
14 & 2 \\
\hline
\end{tabular}

* 140 water sample, 40 swabs \& 12 patient sputa

The specific band of L. pneumophila was seen at 649 bp as shown in Fig. (5) and Table (5). Ramirez et al (1996) found that PCR was able to detect 15 of the 17 infected samples $(88.2 \%)$, this indicate that PCR is a rapid, sensitive and specific test that may greatly simplify the diagnosis of Legionella spp. In another study, Lu et al (1997) reported that PCR method provided a quick and accurate way not only to detect L. pneumophila in the diagnosis of LD but also in the capture and suspected pathogen during epidemiologic investigation when LD outbreaks.

\section{Disinfection procedures for L. pneumo- phila}

We evaluate the efficacy of 4 disinfection modalities a controlled and comparative fashion: chlorine (4 to 6 $\mathrm{mg} / \mathrm{liter}$ ), heat $\left(50\right.$ to $60^{\circ} \mathrm{C}$ ), ozone (1 to 2 $\mathrm{mg} / \mathrm{liter})$, and UV light $(30,000 \mu \mathrm{W}$ $5 / \mathrm{cm}^{2}$ ). Each disinfectant was tested under 3 conditions: (i) nonturbid water at $25^{\circ} \mathrm{C}$, (ii) turbid water at $25^{\circ} \mathrm{C}$ and (iii) nonturbid water at $43^{\circ} \mathrm{C}$.

Our results show that all four methods were efficacious in eradicating $L$. pneumophila from the model plumbing system. The application of chlorine, ozone and UV light showed a 5 to $6 \log$ decrease of L. pneumophila within $6 \mathrm{~h}$ of continuous disinfection. Heat disinfection eliminated all legionellae within $3 \mathrm{~h}$ of disinfection with chlorine, ozone and UV light. UV light produce a $5 \log$ kill within $20 \mathrm{~min}$, while, chlorine, ozone and heat required considerably more time to achieve the same degree of killing (Fig. 6). In this model, however, turbidity was not shown to impair the efficacy of any of the four disinfection methods (Fig. 7).

Higher water temperature $\left(43^{\circ} \mathrm{C}\right)$ enhanced the disinfecting efficacy of chlorine, whereas ozone and UV light were unaffected (Fig. 8). Enhanced efficacy of chlorine in killing $L$. pneumophila at higher temperature was also noted by Kuchta et al (1983). This may be a result of accelerated binding of chlorine to the cell surface Walker et al (1995). However, it should also noted that the addition of approximately $120 \%$ more chlorine was necessary at the higher temperature of $43^{\circ} \mathrm{C}$ to overcome the thermal decomposition of the chlorine residual (Fig. 9). 


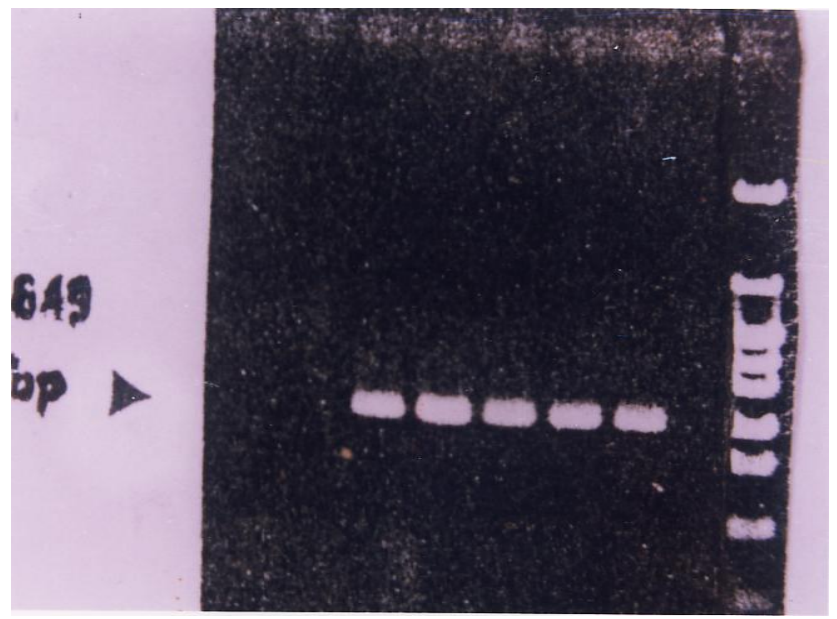

$100 \mathrm{bp}$ $200 \mathrm{bp}$ $300 \mathrm{bp}$ $400 \mathrm{bp}$ $500 \mathrm{bp}$ 600bp $700 \mathrm{bp}$ 800bn

Fig. 5. Agarose (2\%) gel electrophoresis of amplified DNA from contaminated samples performed with primers LmipL 710 and LmipR 1686 and with primers LmipL 920 and Limp R1548, pHY300 PLK and Hae III-digested pHY 300. 2PLK were used as molecular weight markers, the specific band for L. pneumophila was seen at $649 \mathrm{bp}$.

Table 5. Polymerase chain reaction on isolated colonies using the specific primer (LmipL 710 and Limp R 1686 and with primers Limp L 920 and Limp R 1548) as external and internal primers

\begin{tabular}{|lccc|}
\hline \multirow{2}{*}{ Source of sample } & Number of sample & \multicolumn{2}{c|}{ Positive tests } \\
\cline { 3 - 4 } & 140 & No. & $\%$ \\
\hline Water & 40 & 90 & 64.3 \\
Swabs & 12 & 30 & 75 \\
Sputum & 10 & 83.3 \\
\hline
\end{tabular}




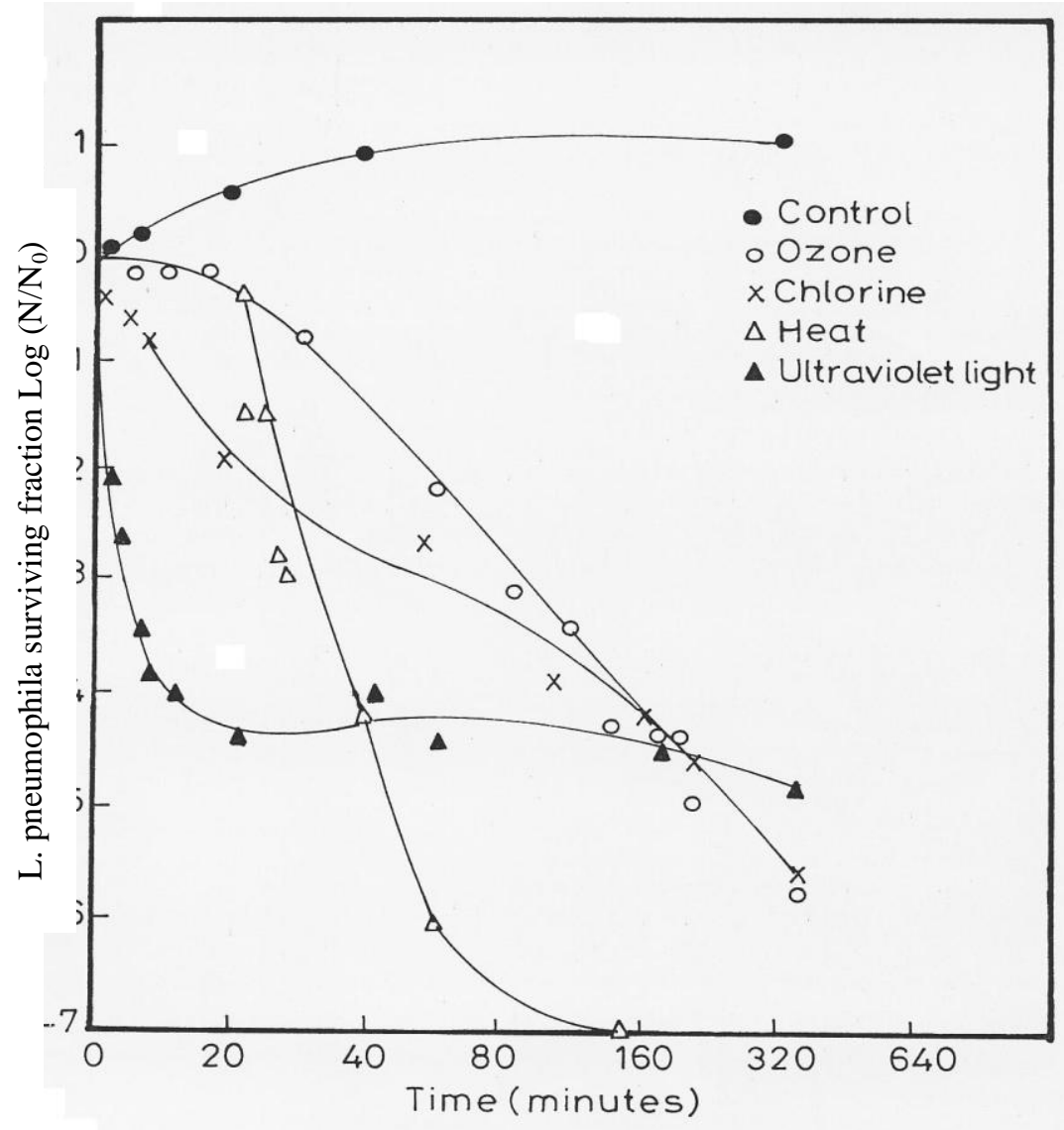

Fig. 6. The comparative efficacy of chlorine, ozone, heat, and UV light in eradicting $L$. pneumophila from a model plumbing system. Each disinfectant technique was evaluated individually in nonturbid water at $25^{\circ} \mathrm{C}$. Mean disinfectant levels were as follow : Chorine (4 to 6 $\mathrm{mg} / \mathrm{L})$, heat $\left(50\right.$ to $\left.60^{\circ} \mathrm{C}\right)$, ozone (1 to $\left.2 \mathrm{mg} / \mathrm{L}\right)$ and $U V$ light $\left(30,000 \mathrm{uW}-\mathrm{s} / \mathrm{cm}^{2}\right)$. The control plot represents a fectant method. The plots are presented in the form $\log (\mathrm{N} / \mathrm{No})$ vs. time $(\mathrm{t})$, where $\mathrm{N}=L$. pneumophila in CFU per milliliter at any time (t) and No $=$ L. pneumophila in CFU per milliliter at $\mathrm{t}=0$ 

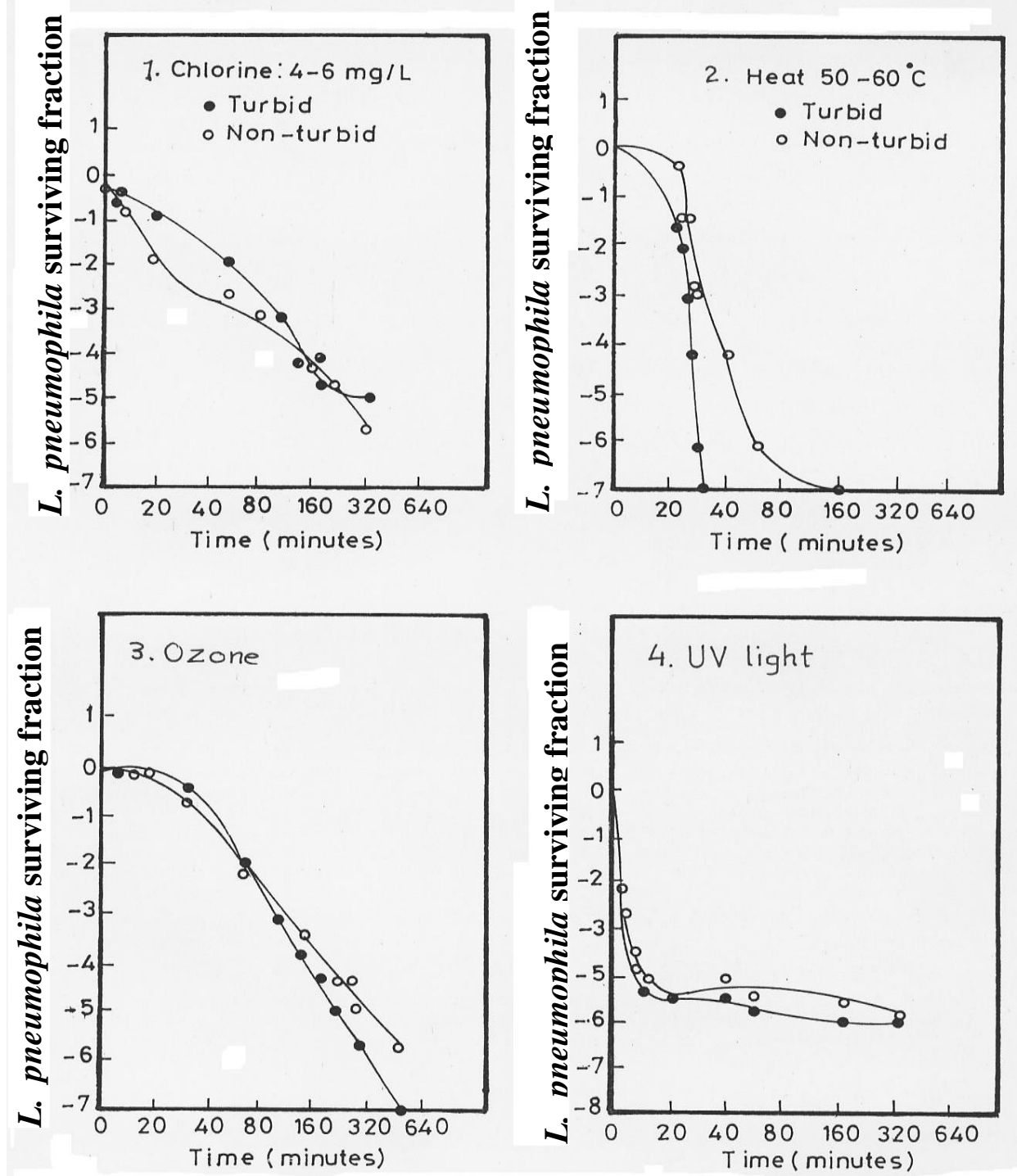

Fig. 7. Effect of turbidity on the efficacy of chlorine (1), heat (2), ozone (3) or UV light (4) Turbid water was prepared by making a 1:10 dilution from concentrated hot water tank effluent samples. This water was determined to have a suspended solids concentration of 4 to $5 \mathrm{mg} / \mathrm{L}$. Tap water was used as a nonturbid medium. The plots are presented in the form $\log (\mathrm{N} / \mathrm{No})$ vs. time $(\mathrm{t})$, where $\mathrm{N}=$ L. pneumophila in CFU per milliliter at any time $(\mathrm{t})$ and $\mathrm{No}=$ L. pneumophila in CFU per milliliter at $\mathrm{t}=0$. 

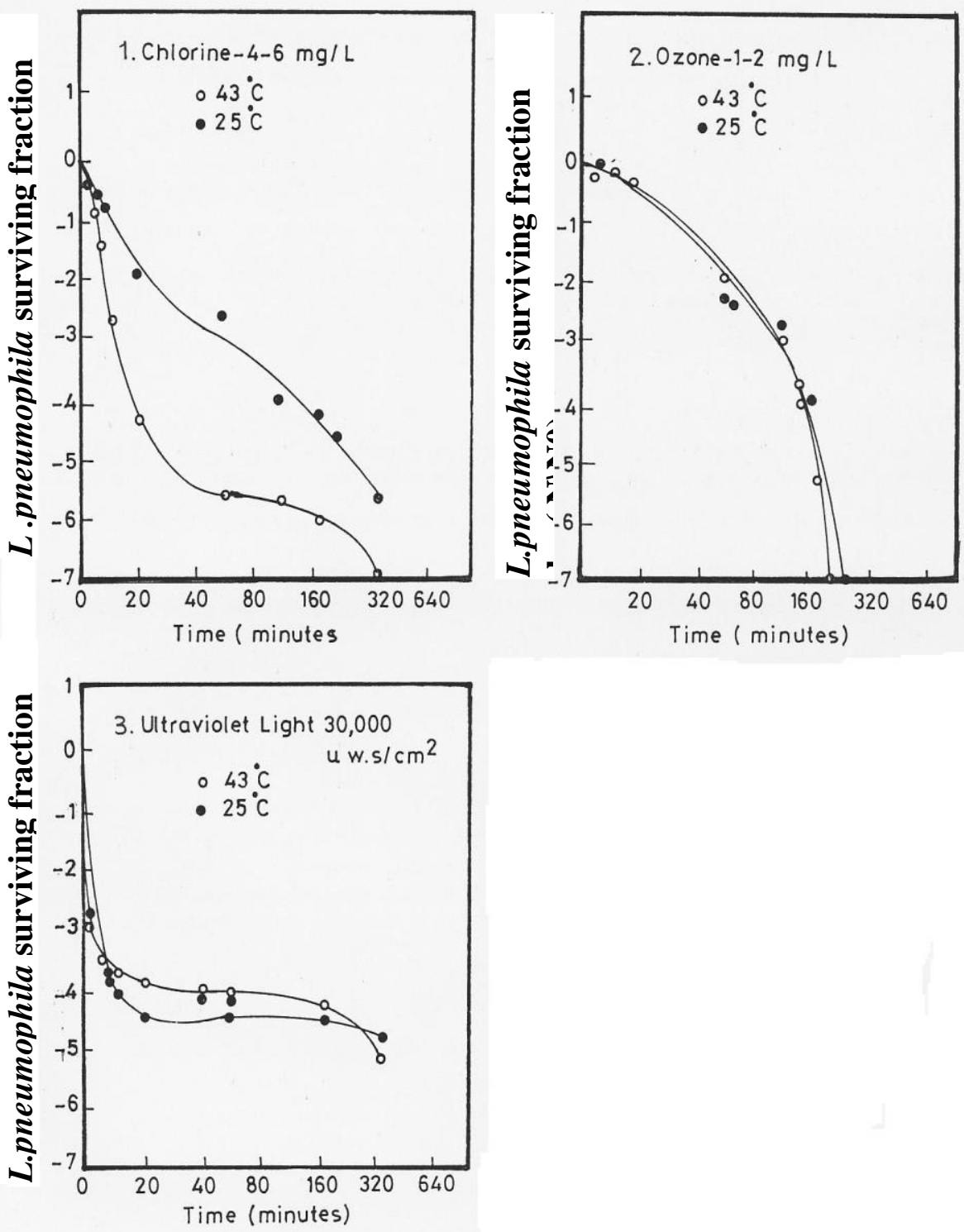

Fig. 8. The effect of temperature on the efficacy of chlorine (1), ozone (2), and UV (3). Increasing the water temperature $\left(25, \mathrm{vs} .43^{\circ} \mathrm{C}\right)$ enhanced the efficacy of chlorine, whereas ozone and UV light were unaffected. The plots are presented in the form $\log (\mathrm{N} / \mathrm{No})$ vs. time $(\mathrm{t})$, where $\mathrm{N}=$ L. pneumophila in CFU per milliliter at any time $(\mathrm{t})$ and $\mathrm{No}=L$. pneumophila in CFU per milliliter at $\mathrm{t}=0$. 


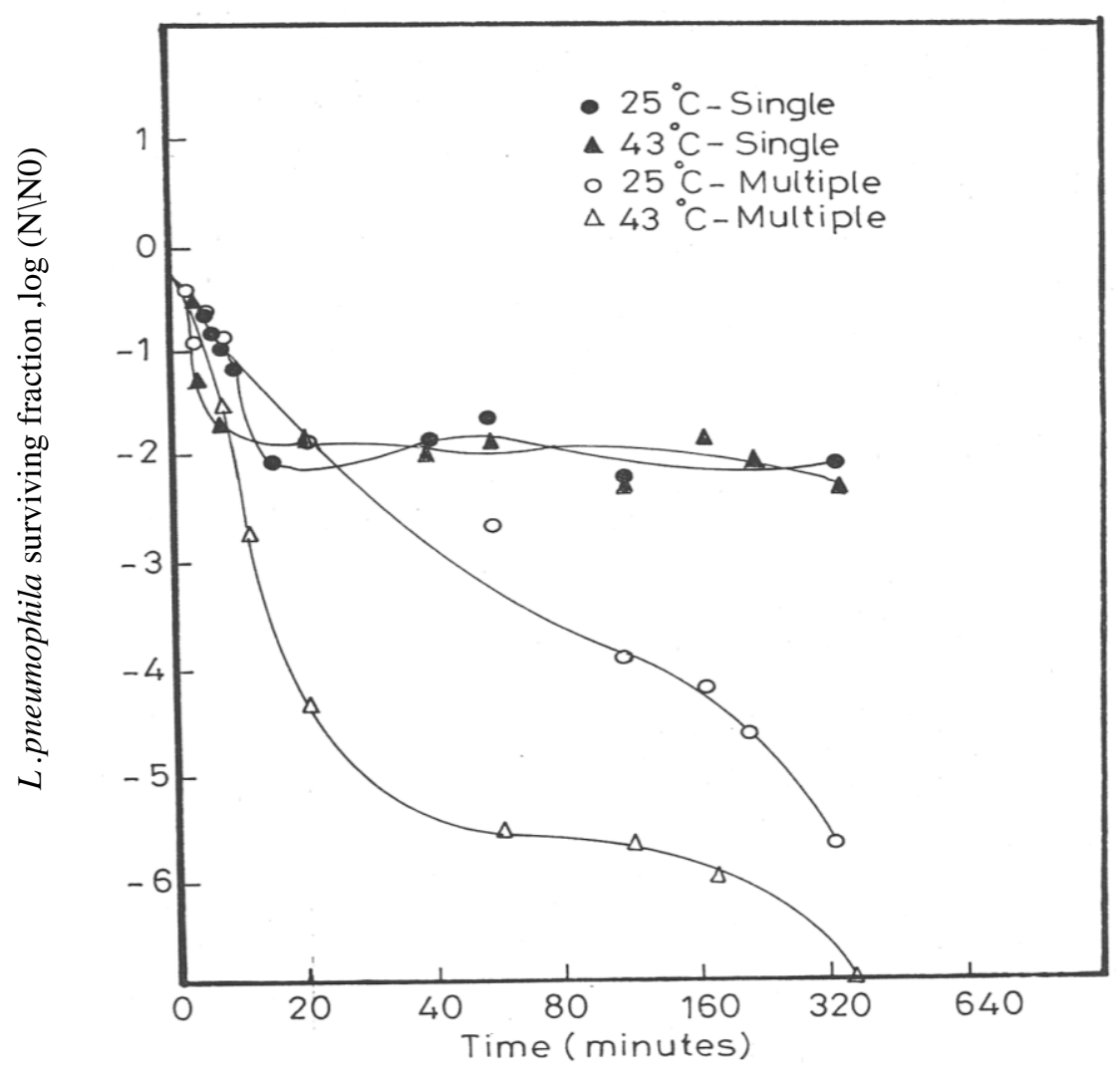

Fig. 9. The efficacy of chlorine disinfection is depended upon maintaining a residual chlorine conc. The plots designated (s) depict Legionella survival when chlorine was administered as a single injection of $8 \mathrm{ml}$. After 20 to $40 \mathrm{~min}$. $L$. pneumophila numbers remained stationary because of diminishing chlorine residual concentration. The plots designated (m) depict a 5 to $6 \log$ decrease of L. pneumophila when the chlorine residual concentration was maintained at 4 to $6 \mathrm{mg} / \mathrm{L}$. by multiple addition. To maintain a chlorine residual of 4 to $6 \mathrm{mg} / \mathrm{L}$ for $6 \mathrm{~h}, 18 \mathrm{ml}$ of chlorine was necessary at $25^{\circ} \mathrm{C}$, whereas $40 \mathrm{ml}$ of chlorine was necessary at $43^{\circ} \mathrm{C}$. The plots are presented in the form $\log (\mathrm{N} / \mathrm{No}) \mathrm{vs}$. time $(\mathrm{t})$, where $\mathrm{N}=$ L. pneumophila in $\mathrm{CFU}$ per milliliter at any time (t) and $\mathrm{No}=$ Hyperchlorination at 4 to $6 \mathrm{mg} /$ liter proved efficacious in suppressing $L$. pneumophila contamination (Harley et al 1997) but when the chlorine residual dropped below $4 \mathrm{mg} /$ liter, cases of nosocomial legionellosis reappeared. 
The application of heat $\left(50\right.$ to $\left.60^{\circ} \mathrm{C}\right)$ eradicated L. pneumophila from the model system within $3 \mathrm{~h}$. These results have been duplicated in hospital water systems where heat has been used as primary disinfection modality Mietzner et al (1997).

An ozone residual of 1 to $2 \mathrm{mg} / \mathrm{liter}$ was shown to effectively control $L$. pneumophila within this model system. Although one study of ozonation in a hospital was inconclusive, the data suggested that ozone could suppress $L$. pneumophila in a large water distribution system (Zacheus and Martikainen 1996).

The efficacy of UV light for eradication of L. pneumophila has been demonstrated in vitro (Moreno et al 1997). In our model system, L. pneumophila concentrations decreased by 4 to $5 \operatorname{logs}$ with UV irradiation within $20 \mathrm{~min}$, whereas chlorine and ozone required at least $3 \mathrm{~h}$ to achieve the same degree of killing (Fig. $6)$. UV light disinfection was not impaired by conditions of turbidity or increased temperature. From the results of this study, UV irradiations appear to have potential as a primary or supplemental in situ disinfectant method.

\section{REFERENCES}

Arnow, P.M.; D. Weil and M.F. Para (1985). Prevalence and significance of Legionella pneumophila contamination of residential hot-tap water systems. J. Inf. Dis., 152(1): 145 - 151.

Baer, H. and C.E. Dasis (1981). Classification and Identification of Bacteria in Medical Microbiology and Infectious Diseases P. 20. (Braude A.). W.B. Saunder Company, Philadelphia.
Baker, F.J. and M.R. Breach (1980). Bacterial Identification Tests. In: Medical Microbiological Techniques, P. 86. Batterworth, London, Boston,

Bibb, W.F.; R.J. Sorg; B.M Thomason; M.D Hicklin ; A.G. Steigerwalt ; D.J. Brenner and M.R. Wulf (1981). Recognition of a second serogroup of Legionella long beachae. J. Clin. Microbiol., 14 : $674-677$.

Boyd, R.F. and J.J. Marr (1980). Isolation, cultivation and identification of microorganisms in: Medical Microbiology, p. 141. Little, Brown and Company, Boston, United States of America.

Buising, K.; M. O'Reilly and A. Paull (2001). Legionella pneumophila not just pneumophila. Med. J. Aust.; 174: 476477.

Campbell, J.; W.F. Bibb; M.A. Lambert; S. Eng; A.G. Steigerwalt; J. Allard; C.W. Moss and D.J. Brenner (1984). Legionella sainthelensi : a new species of Legionella isolated from water near Mt. St. Helens. Appl. Environ. Microbiol., 47: 369-373.

Finegold, S.M. and W.J. Martin (1982). Determination of susceptibility of bacteria to antimicrobial agents; assay of antimicrobial agents in: Diagnostic Microbiology (6 ${ }^{\text {th }} E d$.). P. 542, Mosby Company, London,.

Fliermans, C.B. (1983). Autoecology of Legionella pneumophila. Zentrapbl. Bacteriol. Parasitenkd. Infektionskr. Hyg. Abt. 1 Orig. Reihe A 255: 58-63.

Formica, N.; G. Tallis and B. Zwolak (2000). Legionnaires disease outbreak: Victoria's largest identified outbreak. Commun. Dis. Intell.; 24: 199-202.

Formica, N.; M. Yates and M. Beers (2001). The impact of diagnosis by $L e$ gionella urinary antigen test on the epidemiology and outcomes of Legionnaires 
disease. Epidemiol. Infect., 127: 275280.

Gondaira, F. and J. Sugiyama (1996). Subserogrouping of 49 Legionella pneumophila serogroup 1 strains with monoclonal antibodies by slide latex agglutination method and its usefulness for epidemiologic study. Kansenshogaku Zasshi; 70(7): 673-680.

Gracia-Fulgueiras, A.; C. Navarro and D. Fenoll, (2003). Legionnaires disease outbreak in Murcia, Spain, Emerg. Infect. Dis.; 9: 915 - 921.

Greaves, P.W. (1980) : Methods for the isolation of Legionella pneumophila. $\mathbf{J}$. Clin. Pathol., 33: 581-583.

Harley, V.S.; B.S. Drasar and G. Tovey (1997). The ultrastructure of stressed $L e$ gionella pneumophila. Microbios., 91 (367) : 73-78.

Harrison T.G. and A.G. Taylor (eds) (1988). A Laboratory Manual for Legionella. Wiley, New York.

Hart, C.A. and T. Makin (1991). Legionella in Hospitals: A Review. J. of Hosp. Inf., 18 (Suppl. A): 481-489.

Higa, F.; N. Kusano; M. Tateyoma,; T. Shinzato; N. Arakaki; K. Kawakami and A. Saito (1998) : Simplified quantitative assay system for measuring activities of drugs against intracellular Legionella pneumophila. J. Clin. Microbiol., $36(5)$ : $1392-1398$.

Hoebe, C. and J.L. Kool (2000). Control of Legionella in drinking water system. Lancet, 355: 2093 - 2094.

Jaulhac, B.; M. Reyrolle; Y.K. Sodahlon; S. Jarraud; M. Kubina; H. Monteil; Y. Piemont and J. Etienne (1998). Comparison of sample preparation methods for detection of Legionella pneumophila in culture- positive bronchoalveolar lavage fluids by PCR. J. Clin. Microbiol., $36(7): 2120-2122$.
Jones, G.L. and G.A. Hebert (ed.) (1979). "Legionnaires": the disease, the bacterium, and methodology centers for disease control, Atlanta, Ga. National Technical Information Service. Springfield, Va.

Koide, M. and A. Saito (1995). Diagnosis of Legionella pneumophila infection by polymerase chain reaction. Clin. Infect. Dis., 21(1): 199-201.

Kuchta, J.M.; S.J. States; A.M. McNamara; R.B Wadowsky and R.B. Yee (1983). Susceptibility of Legionella pneumophila to chlorine in tap water. Appl. Environ. Microbiol., 46: 11341139.

Lu, H.; L. Wang and C.Q. Wan (1997). The detection of Legionella pneumophila DNA with polymerase chain reaction in water samples (in process citation). Chung Hua Liu Hsing Ping Hsueh Tsa Chih; 18 (6): 345-347.

Meyers, R.D. (1983). Legionella infections: A Review of five years of research. Rev. Infect. Dis., 5: 258-278.

Mietzner S; R.C. Schwille; A. Farley; E.R. Wald; J.H. Ge; S.J. States; T. Libert; R.M. Wadowsky; S. Miuetzner (1997). Efficacy of thermal treatment and cpper-silver ionization fr controlling Legionella pneumophila in high volume hot water plumbing systems in hospitals. Am. J. Infect. Control, 25 (6): 449451

Miyamoto, H.; M. Ogawa; K. Maruta; Y. Nikaido; C. Yamamoto; H. Taniguchi and S. Yoshida (1995). Temperature effects on Legionella pneumophila killing by and multiplication in phagocytes of guina pigs. Microbiol. Immunol., 39 (9): 647-654.

Moreno, C.; I. de Blas; F. Miralles; D. Apraiz and V. Catalan (1997). A simple method for the eradication of Legionella 
pneumophila from potable water systems. Can. J. Microbiol., 43(12): 1189- 1196. Muraca, P.W.; M.S. Yu and A.R. Goetz (1995). Disinfection of water distribution systems for Legionella : A Review of application procedures and methodologies. Infec. Cont. Hosp. Epid.; 11(2): 79-88.

Ramirez, J.A.; S. Akhee; A. Tolentino; R.D. Miller and J.T. Summersgill (1996). Diagnosis if Legionella pneumophila, Mycoplasma pneumoniae or Chlamydia pneumoniae lower respiratory infection using the polymerase chain reaction on a single throat swab specimen. Diagn.Microbiol. Infect. Dis.,24(1):714.

Ribeiro, C.D.; S.H. Burge and S.R. Palmer (1987). Legionella pneumophila in a hospital water system following a nosocomial outbreak: Prevalence, monoclonal antibody subgrouping and effect of control measures.Epidem. Inf., 98:253262.

Smith, A.L. (1980). Laboratory Identification in: Microbiology and Pathology $\left(12^{\text {th }} \boldsymbol{E d}\right.$.). P. 68. The Mosby Company, London.

Smith, R.P.; A.L. Baltch; M. Franke;
W. Hioe and P. Michelsen (1997). Effect of levofloxacin, erthromycin or rifampicine pretreatment on growth of $L e$ gionella pneumophila in human monocytes. J. Antimicrob. Chemother. Nov., 40(5): $673-678$.

Torrijos, H.J.; L.A. Halpert; N.R. Perez; K. Fujikami; V.S. Figueroa and J.L. Castillo (1995). Atypical pneumonia caused by Legionella pneumophila Report if a secibd case in Mexica. Gac. Mex., 131(5-6): 587-590.

Walker, J.T.; C.W. Mackerness; D. Mallon; T. Makin; T. Williets and C.W. Keevil (1995). Control of Legionella pneumophila in a hospital water system by chlorine dioxide. J. Ind. Microbiol., 15(4) : 384-390.

Wilkinson, H. and B. Fikes (1990). Slide agglutination test for serogrouping Legionella pneumophila and a typical Legionella. Like Organisms. J. Chin. Microbiol., 11 (1) : $99-101$.

Zacheus, O.M. and P.J. Martikainen (1996). Effect of heat flushing on the concentrations of Legionella pneumophila and other heterotrophic microbes in hot water system of apartment buildings. Can. J. Microbiol., 42(8):811-818. 
بحلة اتحاد الجامعات العربية للدراسات والبحوث الزراعية، جامعة عين شمس، القاهرة، 14(2)، 593-611، 2006

دراسات عن التواجد، والتشخيص، والتحكم في بكتيريا الليجيونيلا بنيموفيلا في مصادر المياه المختلفة

[38]

$$
\begin{aligned}
& \text { فتحي عواد منصور 1- السبا علي الشر بيني²- نجوى محمد المرسي } 3 \\
& \text { 1. قسم النبات- كلية العلوم - جامعة المنصورة- المنصسورة- مصر }
\end{aligned}
$$

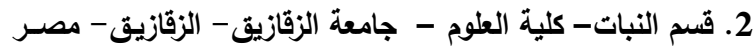

$$
\begin{aligned}
& \text { 3. مركز الجهاز الهضمي - مستثفي جامعة المنصورة- المنصورة- مصر }
\end{aligned}
$$

البكتيريا ووجد أن الطريقة المقترحة بواسطة ربيبيرو ومعاونيه سنة 1987 هي طريقة وفيها يتم حجز البكتيريا علي غشاءونه

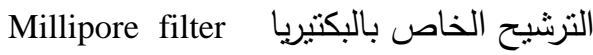

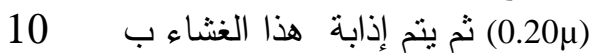
مللي ماء معقم باستخدام جهاز فورتكس بت إنه وبتركيز هذا المعلق الذي يحتوي علي

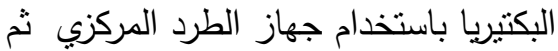

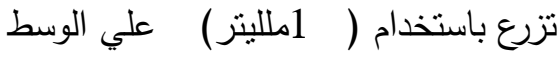
الغذائي المشار إليه.

وقد أظهرت نتائج هذه الدراسة أن 148 عينة من بين العينات المختبرة البالغ عددها (192 عينة) تحتوي علي عزلات بكتيرية ذات خصائص مورفولوجية ومز رعية وكيمو تحوي حيوبة وفسيوليجية مطابقة لخواص بكتيريا

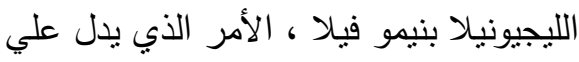

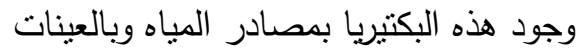
المأخوذة من المرضى ،كذلك وجد أيضا أن الن

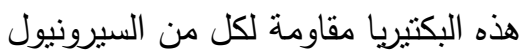
وحمض النالديكسيك وسلفاميثوزول نريمثوبريم
تهدف هذه الدراسة نحو معرفة أنسب

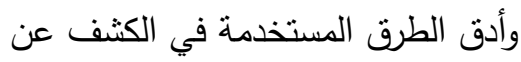

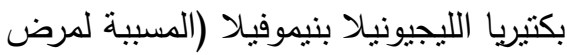
إلا لتهاب الرئوي في الإنسان) وكذللك دراسة طرق القضاء عليها في مصادر المياه المختلفة بمسنتفيات جامعة المنصورة وقد أجري هذا البحث علي 192 عينة ،منها 140 عينة مياه من مصادر مختلفة (دورات

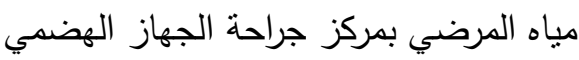

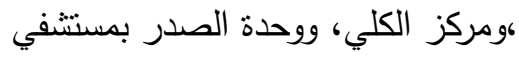
المنصورة الجامعي وأجهزة التكييف المركزي )، 40 عينة قطالة (مسحة) من شبكة المياه 8 (الداخلية بالمسنتفيات ، 12 عينة بصاق عينات من مرضى مصابين بأمراض الكبد و4 عينات من مرضى الفشل الكلوي ، وتم

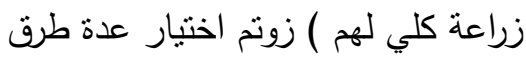

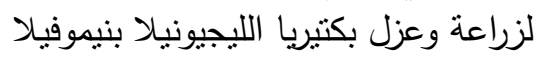
علي المنبت الغذائي المكون من الخميرة والفحم الحيواني Buffered charcoal yeast) الخاص بزراعة هذه 


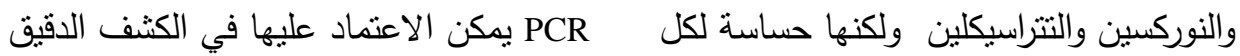
عن هذا النوع من البكتيريا نظرا لحساسيتها فيا لكائا من الجنتاميسين والارثيروميسن

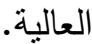

وأخيرا نم استخدام عدة طرق لمكافحة والكلورامفينيكول والدوكس سيكلين

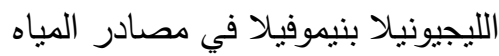
والريفاميسين والسيفاليكسين.

المختلفة بالمستثفيات منها الأوزون، الكلور ، وبعد إجراء إختبار التلبد (التخثر) وجد ان الأثتعة فوق بنفسجية، والتسخين لدرجات

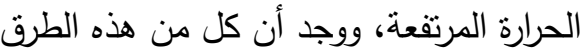

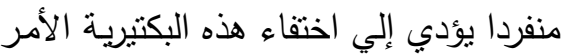

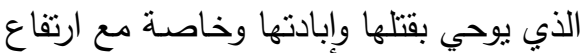

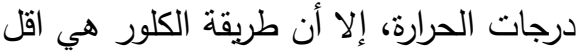
هذه الطرق كفاءة في مقاومة هذه البكتيريا

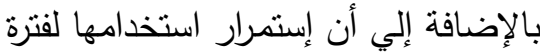

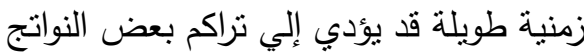
الثانوية غير المرغوب فيها في مصادي الكي تراك بعض النار المباه.

ويتوقف اختيار الطريقة الصحيحة علي أساس طبيعة المكان والإمكانبات المتاحة بها.

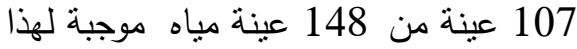

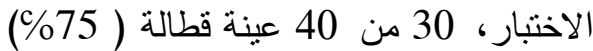
موجبة وجميع عينات المرضي كانت موجبة أي بنسبة (100\%) وظهرت نتيجة التحليل المجهري والفلورسنتي المباشر لجميع هذه العينات ( 192 عينة) باستخدام 14 طراز سيرولوجي بكتيرية الليجيونيلا بنيموفيلا علي اليني النحو التالي: 110عينة موجبة، 82 عينة سالبة. وباستخدام تقنية تفاعل البلمرة المتسلسل (PCR) للكثف عن الليجيونيلا بنيموفيلا وجد إن 130 عينة موجبة لهذا التحليل، 62 عينة سالبة. ولقد أسفرت النتائج إن تقنية

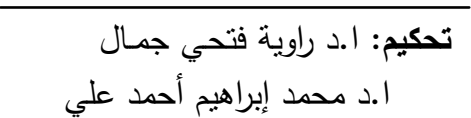

